\title{
Developing Digital Comics as Character Learning Media for Elementary School Students
}

\author{
Fauzatul Ma'rufah Rohmanurmeta, Candra Dewi * \\ Universitas PGRI Madiun, Jl. Setiabudi No.85, Madiun, 63118 Indonesia \\ candra@unipma.ac.id \\ * corresponding author
}

\begin{abstract}
\begin{tabular}{l|l} 
ARTICLE INFO ABSTRACT & ABS
\end{tabular}
Article history

Received May 22, 2020

Revised Dec 15, 2020

Accepted Dec 19, 2020

Keywords

Digital comics

Media

Character learning

Students are expected to learn and conserve the natural environment. Therefore, it is necessary to integrate technology with character values in the form of developing digital comics for environmental preservation based on character values. This study was designed to develop digital comic learning media for environmental preservation based on character values by using of ADDIE development model. were collected using both qualitative and quantitative approaches. Qualitative data were in the form of suggestions, criticisms, responses, and input as described in the questionnaire from the expert judgment. Meanwhile, quantitative data included in the form of percentage values from expert judgment questionnaires arranged on a multilevel scale. Observation, interviews, questionnaires, and tests were used to gather the data. The findings of this study suggested that materials appropriateness and student learning achievement exceed the minimum criteria value set previously. These results show that digital comic learning media based on the character values in integrative thematic learning are declared very feasible and ready to be implemented in integrative thematic learning.
\end{abstract}

Siswa diharapkan untuk belajar dan melestarikan lingkungan alam. Oleh karena itu, perlu untuk mengintegrasikan teknologi dengan nilai-nilai karakter dalam bentuk pengembangan komik digital untuk pelestarian lingkungan berdasarkan nilai-nilai karakter. Penelitian ini bertujuan untuk mengembangkan media pembelajaran komik digital untuk pelestarian lingkungan berdasarkan nilai-nilai karakter dengan menggunakan model pengembangan ADDIE. Data terdiri dari data kualitatif dan kuantitatif. Data kualitatif dalam bentuk saran, kritik, tanggapan, dan input seperti yang dijelaskan dalam kuesioner dari penilaian ahli. Data kuantitatif dalam bentuk nilai persentase dari kuesioner penilaian ahli yang disusun pada skala multilevel. Teknik pengumpulan data adalah observasi, wawancara, kuesioner, dan tes. Hasil uji media pembelajaran komik digital untuk pelestarian lingkungan berdasarkan nilai karakter menunjukkan ketepatan dan siswa mendapatkan hasil belajar di atas nilai kriteria minimum. Hasil ini menunjukkan bahwa media pembelajaran komik digital berdasarkan nilai-nilai karakter dalam pembelajaran tematik integratif dinyatakan sangat layak dan siap diimplementasikan dalam pembelajaran tematik integrative.

This is an open access article under the $\mathrm{CC}-\mathrm{BY}$ license.

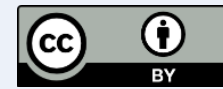

\section{Introduction}

Learning is expected not only to be centered on the teacher, but students must be able to find their own knowledge. In some place Learning is still focused on the transfer of material from teacher to student (Shen, 2004). Based on the results of the presurvey, the use of the computer is rarely used in learning. It is seen that the laboratory is only used for ICT activities. Since the introduction of computers as an educational tool, computers are considered as tools that can support the educational process (Domagk et al., 2010). Now it is very important to introduce technology to students, especially for children's education.

As desired by the Indonesian government that the implementation of learning by implementing a new curriculum called the 2013 Curriculum emphasizes the importance of education in schools can develop human resources who have strong, killed character (Fahmy et al., 2015). In Indonesia, the nation's children are educated to be intelligent people and have good character, and this is the goal of education. Learning strategies that can be used to provide edu- 
cational character by using experimental learning theory. To build a character in students, the teacher must give an example in advance how the character. so the teacher acts as a learning model for students learning characters (Rolina, 2014). In addition to the use of a good strategy must also be accompanied by the use of instructional media that can build character education (Lidyasari, 2014)

Media education in the digital age needs to take into account recent theoretical developments of cultural convergences, media mixes and new forms of participation (Peppler \& Kafai, 2007). Using technology that has not been maximized in learning is the same as not maximizing the giving of character values in thematic learning, especially in science subjects. Children may find visual or animated presentations of news events more interesting and attentiongetting (Cheng \& Lo, 2018). Make students interested in learning can use innovative and creative learning media. Studies suggest that the teacher is a prime determinant of social studies attitude (McGowan et al., 1989). Students in China use mobile applications as a strategy for learning at various levels. (Qian et al., 2018). So the teacher has a very important role to create interesting learning and not make students bored. This project sought to further develop a mobile application into a version suitable for early primary school students to learn ( $\mathrm{Lu}$ et al., 2014).

In this study researchers took five characters values such as being honest, tolerant, hardworking, friendly / communicative, caring for the environment, responsibility. Therefore, it is necessary to integrate technology and character values in thematic learning. Elementary students also worked with place-based education (Morris, 2016) Natural Sciences is expected to be a vehicle for students to learn about themselves and the natural environment, as well as prospects for further development in applying them in their daily lives. In studying natural science students are also expected to be more familiar with the natural environment so that students can preserve the surrounding environment. Integration can be done -using learning media as a means of delivering information based on character values.

Several of the media selection models group media into categories (Reiser \& Gagné, 1982). One of catagories of media is visual media. Digital comics can be defined as images or symbols that are combined using a computer and digitally published. Digital media can help to design the curricula and to ensure students will be exposed to the creation of these different digital media types (Reyna et al., 2017). With digital comic media, teachers can introduce technology to students and students can easily understand the material through stories that are delivered in digital comics.

Comics have long been a part of Indonesia's popular culture which has experienced ups and downs. Illustrative education (comic) could influence participants (Hands et al., 2018) especially influencing students to be able to analyze through the story presented. A comic strip was developed to support the informed process (Grootens-Wiegers et al., 2015). Digital comics can be defined as images or symbols that are aligned in an interesting sequence, which is done entirely by using a computer (as an 'opponent' of a comic that is done conventionally, scanned by a scanner, and then colored with a computer) and digitally published (as other forms of the printed version).

This study focused on character education provided using digital comics (Lee et al., 2013). Often found children with bad characters such as lying, ditching, undisciplined, stealing and damaging the environment. This is very detrimental to the child and society. Character education is important to give because the character of child wild stick to them until they are adults so they need to provide good character education as a provision for students to live in society.

Education programs are essential for the development of the public's environmental literacy (Hutcheson et al., 2018). By using digital comics it is expected that students can have good character in preserving the environment because the environment influences human development and behavior. Suggesting that conservation education is helping to reverse the decline of this species (Feilen et al., 2018). Digital comics based on environmental preservation also provide environmental conservation education to students.

Educating is a complex task which has an internal influences on the educational process (Iglesias Rodríguez et al., 2017).Everything around humans can infleunce the development of human life both directly and indirectly is also an understanding of the environment. From this definition environmental preservation is an effort to protect the ability of the environment against the pressure of change and the negative impacts caused by human activity. As well as maintaining environmental stability to be a place for human, animal, and plant life. It is important that this learning not be confined to the classroom (Parr \& Timperley, 2010). By using digital comics that can be accessed on smartphones, students can study outside the classroom while recognizing the natural surroundings. 
Character as a person's attitude can be formed, innate elements (internal potential), which everyone can be different. Identification of character refers to a cognitive state of meaning the character of someone can be changed, even though the character contains connection, proximity, or similarity between the consumer (Dessart, 2018). This suggests that perception of the moral character of people who are similar to us can be biased by the interference with our moral superiority (Bocian et al., 2018). Character is a set of traits that are always admired as signs of goodness, virtue, and moral maturity. It can be said that the purpose of character learning is to teach certain traditional values, values that are widely accepted as the basis of good and responsible behavior. The more students believe in certain knowledge, the more they can draw exact conclusions from the tentative text (Topcu, 2011). Learning by using digital comics is a creative way to attract students' learning interests. This digital comic is an environmentally friendly character learning media because now many people are damaging their environment and this is also detrimental to others.

This study uses the ADDIE development model which consists of five stages of analysis, design, development, implementation, and evaluation. Researchers develop digital comic learning models based on character education for elementary school students. Digital comics that are developed provide environmental education character for students to support environmental preservation.

\section{Method}

This research employed the ADDIE development model adopted from (Branch \& Stefaniak, 2019) which consists of five stages consist of 1) analyze, (2) design, (3) develop, (4) implement, (5) evaluate.

At the analysis phase, researchers looked at the characteristics of students, identified possible causes of problems in learning and determined the products to be developed. At the design stage, researchers formulated learning objectives and determined learning strategies as stated in the learning implementation plan. The lesson plan is a guide for developing learning media. Afterward, a flowchart before developing the media was made. At the develop stage, researchers created digital comics from the designed draft. Then, in the implementation phase, the researchers conducted a media trial. The trial was carried out with two stages including the first stage was the validity test by subject matter experts and media experts. The second trial was given to elementary school students. The results of this trial were used as the basis for the media evaluating. Lastly, we carried out the evaluation phase. The data obtained in the trial were analyzed to determine the feasibility of the final product (Czaja et al., 2019).

\section{Results and Discussion}

\section{A. Analysis phase}

The needs analysis is carried out to identify the availability of instructional media for character education based on digital technology, the results of the needs analysis that have been carried out namely the absence of learning media based on character education in tune with the mining of information technology and telecommunications.

Available at school are textbooks. With the presence of digital comics, students can improve their literacy and digital literacy and through digital comics students can infer important characters to develop in themselves. Analysis of student characteristics is used to find out the different character of students. Researchers develop digital comics based on character education tailored to student abilities can be used by students from low ability to high ability.

\section{B. Design phase}

At this design stage the researcher designs a product in the form of digital comics after analyzing the syllabus and learning implementation plans. And after planning the learning then making a media design that is digital comic flowchart (Fig. 1.)

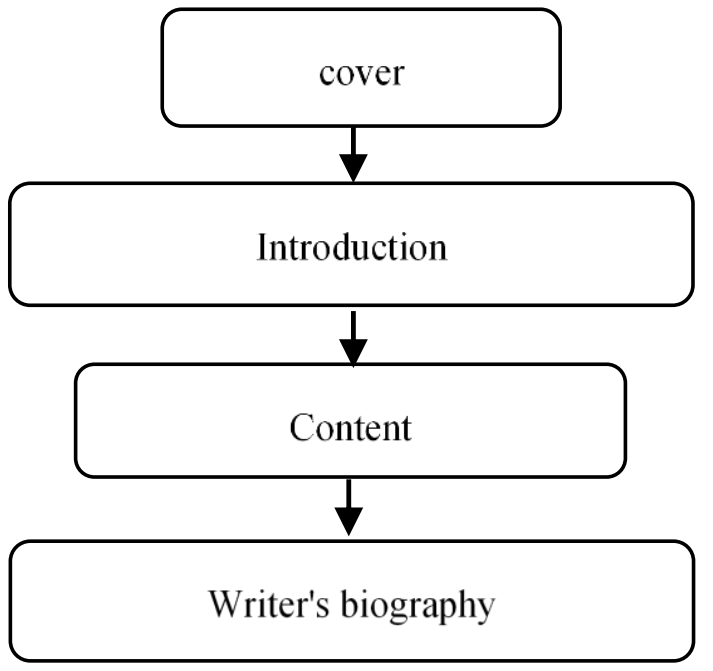

Fig. 1.Flowchart of digital comic

According to Fig. 1 the beginning of making digital comics is making cover, then composing the introduction, making the contents of the certificate and the last page is the writer's biography.

\section{Develop phase}

The developed comic framework consists of cover, foreword, content, and biography of the author which can be seen in Fig. 2 and 3. 

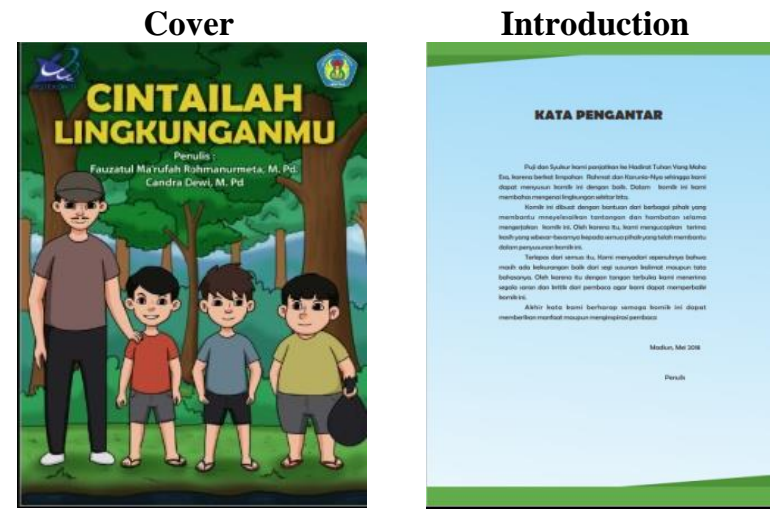

Fig. 2.Front page of digital comic
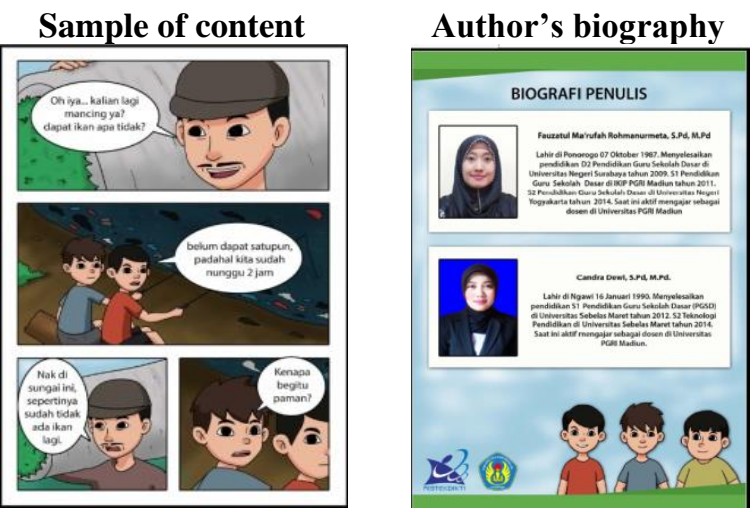

Fig. 3. Content page and author biography

According to Fig. 1 and 2, we can see the framework and pages in the comic. Table 1 shows the front page of the comic consisting of a cover and introduction, and Fig. 2 shows one of the contents and biographies of the author. At this stage, we also developed test as the research instruments. Test indicators can be seen in Table. 1 .

Table 1. Indicator of student test questions

\begin{tabular}{ll}
\hline Basic competencies & Indicator \\
\hline Identify changes that occur in nature, & Explain the effect of \\
the relationship with the use of natural & human activities on \\
resources, and the influence of human & changes nature \\
activities on environmental balance. & Identifying human \\
& $\begin{array}{l}\text { activities in using } \\
\text { natural resources } \\
\text { Analyzing human } \\
\text { activities in } \\
\text { maintaining the } \\
\text { balance of nature }\end{array}$ \\
\hline
\end{tabular}

\section{Implementation phase}

At this stage, comics were used during learning in the class. Learning was done as a learning implementation plan that had been prepared. Learning steps in implementing comics included:

1) Preliminary learning activities

In the preliminary learning activities, the first step taken was the teacher giving greetings and inviting all students to pray according to their respective reli- gions and beliefs; the teacher checked for readiness by filling out the attendance sheet and checking the neatness of the clothes, position, and seating adjusted to the learning activities; informing the theme to be learned namely about "Humans and the Environment". The teacher gave apperception to the students asking questions about the theme to be given

\section{2) Core activities}

Students observed pictures showing examples of conditions in the surrounding natural environment. Then students observed and analysed images carefully. Students answered the questions in the student book based on the observation of the picture. Afterward, students read digital comics, and the teacher appointed one student to read the reading and asks other students to listen. After reading, students were asked to make a mind map. Mind maps were made based on information contained in digital comics. Students were asked to discuss to know the rights, obligations, and human responsibilities to the environment. Then each group presented the results of their discussion.

\section{3) End activities}

Teacher and students summarized learning outcomes for a day. Teacher and students asked questions about the material that has been learned (to find out the results of the achievement of the material). The teacher gave the opportunity for students to express their opinions about the learning that has been followed. Teacher then invited all students to pray according to their own religion and beliefs (to end learning activities).

\section{E. Evaluation phase}

1) Data Analysis of Science Teaching Materials Experts (Table 2).

According to Table 2, analysis of data from material experts received an overall total score on environmental conservation digital comic learning media based on character values with a percentage of $87 \%$ and declared very valid.

Table 2. Data Analysis of Science Teaching Materials Experts

\begin{tabular}{ccccc}
\hline No. & Assessment Aspects & TSEV & $\begin{array}{c}\text { S- } \\
\text { max }\end{array}$ & $\begin{array}{c}\text { V } \\
(\boldsymbol{\%})\end{array}$ \\
\hline 1 & Learning objectives & 18 & 20 & 90 \\
2 & Presentation of Material & 35 & 40 & 87,5 \\
3 & Effectiveness of Learning & 20 & 24 & 83,3 \\
& Media Functions & & & \\
4 & Language & 14 & 16 & 87,5 \\
& $\quad$ Total & 87 & 100 & 348,3 \\
& Average percentage (\%) & & & 87 \\
\hline
\end{tabular}


2) Data Analysis from the Digital Comic Media Expert

Table 3. Data Analysis from the Digital Comic Media Expert

\begin{tabular}{ccccc}
\hline No. & Assessment Aspects & TSEV & $\begin{array}{c}\text { S- } \\
\mathbf{m a x}\end{array}$ & $\begin{array}{c}\text { V } \\
(\boldsymbol{\%})\end{array}$ \\
\hline 1 & Learning objectives & 18 & 20 & 90 \\
2 & Technical Digital Comics & 22 & 24 & 91,67 \\
3 & Effectiveness of Digital & 20 & 24 & 83,3 \\
& Comic Media Functions & & & \\
& Total & 60 & 68 & 264,97 \\
& Average percentage (\%) & & & 88 \\
\hline
\end{tabular}

The results of the questionnaire by digital comic media experts obtained the overall score of the digital comic media character-based environmental preservation with a percentage of $88 \%$ and declared very valid.

3) Analysis of Field Test Data by Fifth Grade Elementary School Teachers

Analysis of the value of Field Test Data by fifth grade Elementary School Teachers can be presented in the following average values in Fig. 4

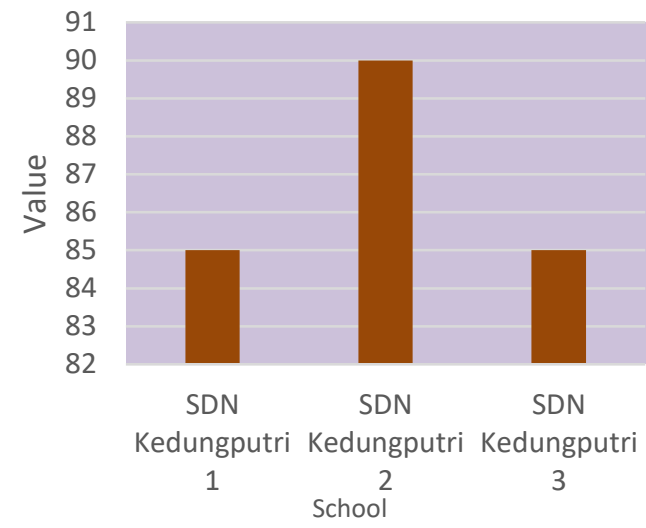

Fig. 4.Data Analysis by fifth-grade Elementary School Teachers

From the presentation of Fig. 4, we can see the validity value at Sumoroto 1 Elementary school is $85 \%$, Sumoroto 2 Elementary school is $90 \%$ and Sumoroto 3 Elementary school is $85 \%$. It can be concluded that the total score of the trial questionnaire on the average fifth-grade elementary school teachers in character-based digital comic learning media is $87 \%$ and is declared very valid.

4) Analysis of Field Test Data by Large Groups Student

Analysis of the value of students can be presented in the following average values of student learning outcomes. From the presentation of Fig. 5, it can be concluded that the average values of the fifth grade of Elementary School has above minimum value
(75), which is 80,84 , and 84 . The average of all values is 82,67 . This shows that the product developed is feasible to use.

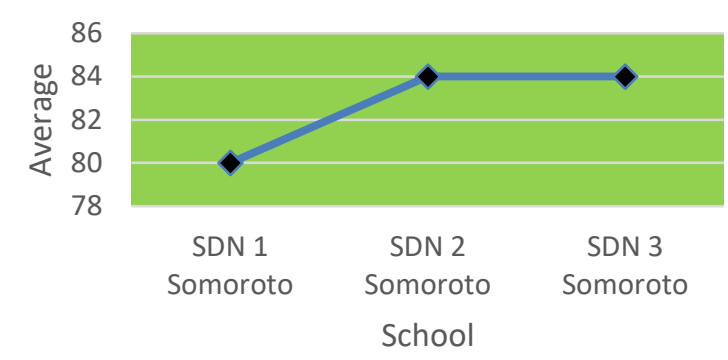

Fig. 5.Class Average Diagram

Analysis of the results of the feasibility test by material experts, obtained the feasibility level of $87 \%$, so that it is classified as very valid and can be implemented. No score 2 is obtained, scores that often appear are 3 and 4 . The results of the scoring prove that the learning media is valid because the material experts also did not provide comments and suggestions for revision.

Analysis of the results of the feasibility test by Media Expert, obtained the feasibility level of $88 \%$, so that it is classified as very valid and can be implemented. There is no score 2 , the scores that often appear are 3 and 4 . The results of the supervision do not prove the learning media to be valid because media experts also provide comments and suggestions for revision.

The development of digital comics is carried out through five stages including analysis, design, development, implementation and evaluation (Reinbold, 2013). The activity analysis stage is analyzing the learning syllabus, analyzing student characteristics, analyzing learning problems, determining learning objectives, determining the product to be developed. Then proceed with the design stage that is making a learning implementation plan that will be used as a reference in designing digital comic products. The development phase begins by applying a digital comic flowchart to the actual comic design and incorporating characters in the comic story. And do the preparation of instruments to conduct trials. After that, it is continued at the implementation stage which is to conduct a trial applying digital comics in student learning based on the learning plans that have been made. The media feasibility test is carried out by media experts and material experts. And at the evaluation stage that is evaluating the results of trials conducted on experts and students to determine the feasibility of the product.

There are many creative and interesting ways that are done for learning. Storytelling has been used for thousands of years as a way for someone to deliver 
learning material (Beard \& Rhodes, 2002). Learning by using comics is an interesting way to convey information to students because in the comics there is narration and images that can make it easier for students to understand the narration (Negrete, 2013). By reading stories and seeing pictures in digital comics will make it easier for students to understand the story and take the character's mandate from the story. A person's character will influence the person's attitude in getting along. The environment can also affect a person's character and attitude. Through a good school environment is expected to provide good character for students (Bocian et al., 2018). A person's character can distinguish attitudes and behavior between one person and another (Rokhman et al., 2014). Digital comics are suitable for elementary school students because they think that learning by using comics is very fun and informative (GrootensWiegers et al., 2015).

\section{Conclusion}

The development of digital comics is carried out through five stages, including analysis, design, development, implementation, and evaluation. The activity analysis stage is analysing the learning syllabus, analysing student characteristics, analysing learning problems, determining learning objectives, determining the product to be developed. Then proceed with the design stage that is making a learning implementation plan that will be used as a reference in designing digital comic products. The development phase begins by applying a digital comic flowchart to the actual comic design and incorporating characters in the comic story. And do the preparation of instruments to conduct trials. Afterward, it is continued at the implementation stage, which is to conduct a trial applying digital comics in student learning based on the learning plans that have been made. The media feasibility test was carried out by media and material experts. At the evaluation stage, evaluating the results of trials conducted on experts and students to determine the feasibility of the product was done.

\section{References}

Beard, C., \& Rhodes, T. (2002). Experiential Learning: Using comic strips as 'reflective tools' in adult learning. Journal of Outdoor and Environmental Education, 6(2), 58-65. https://doi.org/10.1007/bf03400756

Bocian, K., Baryla, W., Kulesza, W. M., Schnall, S., \& Wojciszke, B. (2018). The mere liking effect: Attitudinal influences on attributions of moral character. Journal of Experimental Social Psychology, 79(October 2017), 9-20. https://doi.org/10.1016/j.jesp.2018.06.007
Branch, R. M. R., \& Stefaniak, J. E. (2019). Instructional design theory. In Open and Distance Education Theory Revisited (pp. 8594). springer.

Cheng, B. K. L., \& Lo, W. H. (2018). Melodramatic animation in crime news and news information learning. Journalism. https://doi.org/10.1177/1464884918776747

Czaja, S. J., Boot, W. R., Charness, N., \& Rogers, W. A. (2019). Designing for older adults: Principles and creative human factors approaches. In Designing for Older Adults (3rd ed.). CRC press. https://doi.org/10.1201/b22189-8

Dessart, L. (2018). Do ads that tell a story always perform better? The role of character identification and character type in storytelling ads. International Journal of Research in Marketing, 35(2), 289-304. https://doi.org/10.1016/j.ijresmar.2017.12.009

Domagk, S., Schwartz, R. N., \& Plass, J. L. (2010). Interactivity in multimedia learning: An integrated model. Computers in Human Behavior, 26(5), 1024-1033. https://doi.org/10.1016/j.chb.2010.03.003

Fahmy, R., Bachtiar, N., Rahim, R., \& Malik, M. (2015). Measuring Student Perceptions to Personal Characters Building in Education: An Indonesian Case in Implementing New Curriculum in High School. Procedia - Social and Behavioral Sciences, 211, 851-858. https://doi.org/10.1016/j.sbspro.2015.11.112

Feilen, K. L., Guillen, R. R., Vega, J., \& Savage, A. (2018). Developing successful conservation education programs as a means to engage local communities in protecting cotton-top tamarins (Saguinus oedipus) in Colombia. Journal for Nature Conservation, 41, 44-50. https://doi.org/10.1016/j.jnc.2017.10.003

Grootens-Wiegers, P., de Vries, M. C., van Beusekom, M. M., van Dijck, L., \& van den Broek, J. M. (2015). Comic strips help children understand medical research. Targeting the informed consent procedure to children's needs. Patient Education and Counseling, 98(4), 518-524. https://doi.org/10.1016/j.pec.2014.12.005

Hands, T., Shaw, A., Gibson, M., \& Miller, K. (2018). People and their plants: The effect of an educational comic on gardening intentions. Urban Forestry and Urban Greening, 30 (January), 132-137. https://doi.org/10.1016/j.ufug.2018.01.017

Hutcheson, W., Hoagland, P., \& Jin, D. (2018). Valuing environmental education as a cultural ecosystem service at Hudson River Park. Ecosystem Services, 31, 387-394. https://doi.org/10.1016/j.ecoser.2018.03.005

Iglesias Rodríguez, A., García Riaza, B., \& Sánchez Gómez, M. C. (2017). Collaborative learning and mobile devices: An educational experience in Primary Education. Computers in 
Human Behavior, 72, 664-677. https://doi.org/10.1016/j.chb.2016.07.019

Lee, C. Y., Pan, P. J. Der, Liao, C. J., Chen, H. Y., \& Walters, B. G. (2013). E-character education among digital natives: Focusing on character exemplars. Computers and Education, 67, 5868. https://doi.org/10.1016/j.compedu.2013.02.020

Lidyasari, A. T. (2014). Developing PGSD Students Character through Experience Learning Theory. Procedia - Social and Behavioral Sciences, 123, 189-195. https://doi.org/10.1016/j.sbspro.2014.01.1414

Lu, J., Meng, S., \& Tam, V. (2014). Learning Chinese characters via mobile technology in a primary school classroom. Educational Media International, 51(3), 166-184. https://doi.org/10.1080/09523987.2014.968448

McGowan, T. M., Sutton, A. M., \& Smith, P. G. (1989). Instructional Elements Influencing Elementary Student Attitudes toward Social Studies. Theory and Research in Social Education, 18(1), 37-52. https://doi.org/10.1080/00933104.1990.10505603

Morris, R. V. (2016). Historic Preservation and Elementary Student Extracurricular Community Service. The Social Studies, 107(6), 181185. https://doi.org/10.1080/00377996.2016.1190916

Negrete, A. (2013). Constructing a Comic to Communicate Scientific Information about Sustainable Development and Natural Resources in Mexico. Procedia - Social and Behavioral Sciences, 103, 200-209. https://doi.org/10.1016/j.sbspro.2013.10.327

Parr, J. M., \& Timperley, H. S. (2010). Multiple "black boxes": Inquiry into learning within a professional development project. Improving Schools, 13(2), 158-171. https://doi.org/10.$1177 / 1365480210375349$

Peppler, K. A., \& Kafai, Y. B. (2007). From SuperGoo to Scratch: Exploring creative digital media production in informal learning. Learning, Media and Technology, 32(2), 149-
166. https://doi.org/10.1080/17439880701343337.

Qian, K., Owen, N., \& Bax, S. (2018). Researching mobile-assisted Chinese-character learning strategies among adult distance learners. Innovation in Language Learning and Teaching, 12(1), 56-71. https://doi.org/10.1080/17501229.2018.1418633

Reinbold, S. (2013). Using the ADDIE Model in Designing Library Instruction. Medical Reference Services Quarterly, 32(3), 244-256. https://doi.org/10.1080/02763869.2013.80685 9

Reiser, R. A., \& Gagné, R. M. (1982). Characteristics of Media Selection Models. Review of Educational Research, 52(4), 499-512. https://doi.org/10.3102/00346543052004499

Reyna, J., Hanham, J., \& Meier, P. (2017). A taxonomy of digital media types for LearnerGenerated Digital Media assignments. ELearning and Digital Media, 14(6), 309-322. https://doi.org/10.1177/2042753017752973

Rokhman, F., Hum, M., Syaifudin, A., \& Yuliati. (2014). Character Education for Golden Generation 2045 (National Character Building for Indonesian Golden Years). Procedia Social and Behavioral Sciences, 141, 11611165. https://doi.org/10.1016/j.sbspro.2014.05.197

Rolina, N. (2014). Developing Responsibility Character for University Student in ECE through Project Method. Procedia - Social and Behavioral Sciences, 123, 170-174. https://doi.org/10.1016/j.sbspro.2014.01.1411

Shen, H. H. (2004). Level of cognitive processing: Effects on character learning among nonnative learners of chinese as a foreign language. Language and Education, 18(2), 167-182. https://doi.org/10.108009500780408666873

Topcu, M. S. (2011). Turkish elementary student teachers' epistemological beliefs and moral reasoning. European Journal of Teacher Education, 34(1), 99-125. https://doi.org/10.1080/02619768.2010.534132 